\title{
ANALISIS KOMPETENSI DAN PEMAHAMAN TFRAUD DALAM MENDETEKSI FRAUD PADA KOPERASI SIMPAN PINJAM
}

\author{
Alit Erlina Wati ${ }^{1}$, Arie Indraswarawati ${ }^{2}$, Trisna Windika $\mathrm{P}^{3 *}$ \\ ${ }^{1,2,3}$ Akuntansi, Fakultas Ekonomi Bisnis dan Pariwisata Universitas Hindu Indonesia \\ *e-mail: aliterlina@unhi.ac.id
}

DiPublikasi: 01/07/2021

https://doi.org/10.22225/kr.13.1.2021.136-146

\begin{abstract}
This study aims to determine to what extent the competence and understanding of fraud possessed by internal supervisors, heads and managers in detecting fraud that occurs in savings and loan cooperatives in East Denpasar District is adequate or not. The population in this study are internal supervisors and managers of savings and loan cooperatives in the East Denpasar area which are still actively operating. Determination of the smple used in this research is purposive sampling technique. Data collection using a questionnaire. Testing data with validity and reliability, data analysis using interval class method.

The results showed that the competence of managers, chairmen and internal supervisors seen from accounting knowledge was adequate with an average value of 3.98, judging from the attitudes possessed with a score of 4.45 in the very adequate category that upholds Pancasila values, skills. owned is very adequate with a score of 4.22. Understanding of fraud from managers, chairmen and supervisors with an average score of 3.83 in the adequate category and the ability to handle fraud that has an average of 4.44 in the very adequate category.
\end{abstract}

Keywords: Competence, fraud, detection, manager

\begin{abstract}
Abstrak
Penelitian ini bertujuan untuk mengetahui sejauh mana kompetensi dan pemahaman fraud yang dimiliki oleh pengawas , pimpinan dan manajer dalam mendeteksi fraud yang terjadi pada koperasi simpan pinjam di Kecamatan Denpasar Timur sudah memadai atau tidak. Populasi dalam penelitian ini adalah pengawas dan pengurus koperasi simpan pinjam di wilayah Denpasar Timur yang masih aktif beroperasi. Penentuan sampel yang digunakan dalam penelitian ini adalah teknik purposive sampling, yang memenuhi kriteria sampel 61 responden. Pengumpulan data menggunakan kuesioner. Pengujian data dengan validitas dan reliabilitas, analisis data menggunakan metode kelas interval.

Hasil penelitian menunjukkan bahwa kompetensi yang dimiliki manajer, ketua dan pengawas dilihat dari pengetahuan akuntansi sudah memadai dengan nilai rata-rata 3,98, ditinjau dari sikap yang dimiliki dengan skor 4,45 dalam kategori sangat memadai yang menjunjung tinggi nilai-nilai pancasila, keterampilan yang dimiliki sangat memadai dengan skor 4.22. Pemahaman tentang fraud dari manajer, ketua dan pengawasdengan skor rata-rata 3,83 dalam katagori memadai dan kemampuan dalam mendeteksi fraud yang dimilikisecara rata-rata sebesar 4,44 dalam katagori sangat memadai.
\end{abstract}

Kata Kunci : Kompetensi, fraud, deteksi, manajer

\section{PENDAHULUAN}

Koperasi memiliki andil besar sebagai wadah kegiatan perekonomian rakyat, karena sebagai suatu badan usaha yang berbadan hukum yang diarahkan dan didorong untuk ikut berperan dalam mensejahterakan anggotanya pada khususnya dan masyarakat pada umumnya sesuai tujuannya.

Perhatian pemerintah dengan memberikan pembinaan berupa peningkatan pembangunan modal, bimbingan dan penyuluhan usaha, pengembangan dan tata laksana, pendidikan dan pelatihan serta peningkatan penelitian/survey operasi. Tantangan yang dihadapi koperasi adalah bagaimana mengembangkan koperasi menjadi sehat, maju, kuat dan mandiri serta memiliki daya saing sehingga mampu meningkatkan peranan dalam perekonomian nasional sekaligus tujuan yang akan dicapai oleh koperasi. Koperasi simpan pinjam (KSP) sebagai suatu lembaga ekonomi yang bergerak dalam bidang perbankan harus dapat menjaga kepercayaann terutama para kreditur sebagai tanggungjawab atas penempatan dana nasabah dengan menyajikan laporan keuangan yang 
berkualitas sebagai dasar untuk mengambil keputusan.

Sama dengan organisasi yang lainnya koperasi juga memiliki perangkat organisasi sesuai dengan (Undang-Undang Nomor 17 Tahun 2012 Tentang Perkoperasian, 2012) yang menyatakan bahwa perlengkapan koperasi terdiri dari rapat anggota, pengurus dan pengawas. Menurut (Tentang Penyelenggaraan Dan Pembinaan Koperasi, 2018) tentang Penyelenggaraan dan Pembinaan Koperasi menyatakan rapat anggota adalah rapat yang diselenggarakan oleh pengurus yang dihadiri oleh anggota, pengurus dan pengawas. Pengurus adalah perangkat organisasi koperasi yang bertanggungjawab penuh atas kepengurusan koperasi untuk kepentingan dan tujuan koperasi serta mewakili koperasi baik di dalam maupun di luar pengadilan sesuai dengan ketentuan anggaran dasar.

Kemampuan pengurus untuk mencapai tujuan koperasi terletak pada fungssi perencanaan dan pengawasan yang telah ditetapkan. Fungsi perencanaan merupakan langkah awal untuk mencapai tujuan. Pengawasan merupakan tindakan terhadap proses kegiatan untuk mengetahui hasil pelaksanaan, kesalahan, kegagalan, kemudian dilakukan perbaikan dan mencegah terulangnya kembali kesalahan tersebut. Pengawas adalah perangkat organisasi yang mendapat kuasa dari rapat anggota untuk mengawasi pelaksanaan keputusan rapat anggota yang khususnya menyangkut organisasi, kelembagaan, pendidikan, serta penyuluhan. Pengawas bertugas melakukan penilaian yang independen untuk menguji dan mengevaluasi kegiatan - kegiatan yang ada di koperasi, dengan tujuan membantu pengurus agar dapat melaksanakan tanggung jawabnya secara efektif (Paula Chrestina Hendrawati, 2017). Lemahnya sistem pengawasan sering menimbulkan kerugian, kesalahan, in-efisiensin dan kecurangan/Fraud , untuk menghindari hal tersebut dalam pengelolaan koperasi maka diperlukan sistem pengawasan dalam koperasi yang dilakukan oleh badan pengawas. Pengawas dalam struktur organisasi koperasi yang berfungsi sebagai auditor intern dan tidak terlibat dalam aktivitas operasional koperasi. Sehingga dalam melakukan aktivitasnya baik pengurus maupun badan pengawas harus memiliki kompetensi yang memadai dalam menjalankan aktivitasnya.

Kecurangan biasa disebut dengan fraud adalah tindakan curang yang dilakukann dengan sengaja untuk menguntungkan satu pihak secara tidak adil atau melanggar hukum yang mengakibatkan kerugian di pihak lain. Tindakan fraud yang dilakukan dapat menimbulkan banyak kerugian baik secara material maupun non material seperti, hancurnya reputasi organisasi, kerugian keuangan, rusaknya moralitas karyawan serta dampak-dampak negatif lainnya.

Kompetensi kerja adalah kemampuan kerja setiap individu yang mencakup aspek pengetahuan, ketrampilan dan sikap kerja setiap individu sesuai dengan standar yang ditetapkan (UU No 13 Tahun 2003). Pengawas dan pengurus harus memiliki kemampuan berupa pengetahuan akuntansi misalnya memahami laporan keuangan, memahami organisasi dan manajemen serta memahami jati diri koperasi serta pengawas mempunyai pengetahuan yang mirip dengan akuntan. Pengawasan yang lemah akibat kemampuan personil badan pengawas sering menjadi persoalan sendiri bahkan di banyak koperasi, pengawas justru kerap menjadi pajangan untuk menyebutkan koperasi itu lengkap secara organisasi. Kompetensi diperoleh dari latar belakang pendidikan di bidang akuntansi, pelatihan-pelatihan yang telah diikuti, dan peran aktif dalam melaksanakan tugas-tugasnya sebagai pengawas. Sesuai (Permen KUMK No, 15/Per/M.KUMK/IX/2015, n.d.) tentang usaha simpan pinjam bahwa pengelola koperasi wajib memiliki setifikasi standar kompetensi yang dikeluarkan oleh lembaga sertifikasi profesi yang sudah mendapat lisensi sesuai peraturan perundang-undangan, sehingga SDM koperasi khususnya pengelola KSP maupun unit simpan pinjam (USP) memiliki kompetensi yang dipersyaratkan untuk mengelola koperasi.

Pemahaman tentang kecurangan/fraud merupakan suatu kemampuan seseorang untuk mengenal dan mengerti tentang Fraud. Tingkat pemahaman tentang fraud ini dapat diukur dari paham seseorang terhadap kegiatan-kegiatan terjadinya fraud, pihak-pihak yang terlibat dan bentuk modus fraud.

Terjadinya berbagai kasus di koperasi seperti dana nasabah koperasi serba usaha Dana Asih banjar Negari Desa Singapadu Tengah Sukawati sebesar Rp 22 milliar yang dilarikan ketua. Kejadian ketua koperasi serba usaha Banjar Triwangsa Sebali Desa Keliki Tegalalang tidak 
bisa mempertanggungjawabkan dana nasabah senilai Rp 2,1 miliar. (NusaBali.com). Dari kasus ini menunjukkan betapa rendahnya kompetensi dan pemahaman fraud yang dimiliki dari badan pengawas yang tidak mampu mendeteksi secara dini terjadinya kecurangan.

Kota Denpasar merupakan lokasi perkembangannya koperasi paling pesat. Adapun wilayah pengembangan koperasi terbesar yaitu ada di wilayah Denpasar Timur yaitu sebanyak 320 koperasi yang terdiri dari berbagai jenis koperasi seperti Koperasi Unit Desa(KUD), Koperasi serba Usaha (KSU), Koperasi Simpan Pinjam (KSP), Koperasi pegawai Negeri (KPN), Koperasi Karyawan (Kopkar), Koperasi Jasa (Kopja) dan Koperasi.

Berdasarkan latar belakang masalah yang telah diuraikan, maka perumusan masalah dalam

\section{TINJAUAN PUSTAKA}

Koperasi merupakan kumpulan orang yang memiliki tujuan dalam memenuhi kebutuhan ekonomi melalui badan usaha yang dijalankan anggota sebagai pemilik sekaligus pengguna jasa koperasi sesuai dengan (Undang-Undang Nomor 25 Tahun 1992 Tentang _Perkoperasian, 1992) Pada dasarnya koperasi memperoleh keuntungan dari hasil pembelian atau penjualan yang dilakukan secara efisien, bukan perhitungan untung rugi yang digunakan koperasi terhadap anggotanya, akan tetapi sisa hasil usaha dari adanya efisiensi tersebut.

Berdasarkan pada agency theory, kualitas dan informasi dari laporan keuangan yang dihasilkan pihak agen (manajemen koperasi) yaitu pengurus dan laporan pemeriksaan badan pengawas dapat berfungsi sebagai alat untuk memberikan keyakinan kepada anggota koperasi selaku principle bahwa mereka menerima return atas dana yang diinvestasikan, serta sebagai sumber informasi mengenai posisi keuangan, kinerja serta perubahan posisi keuangan koperasi. Namun sebaliknya laporan yang dihasilkan tidak berkualitas, maka anggota koperasi dan kreditor selaku pihak principle akan ragu untuk memberikan dananya untuk dikelola karena tidak adanya kepastian atas return dana yang telah diberikan. Laporan keuangan yang dihasilkan oleh pengurus koperasi kemudian akan dikoreksi oleh badan pengawas koperasi selaku pihak auditor internal, sehingga laporan keuangan yang disampaikan kepada anggota dapat diandalkan dan tidak penelitian ini adalah bagaimanakah kompetensi dan pemahaman tentang fraud yang dimiliki pengawas, pengurus dan manajer dalam mendeteksi terjadinya fraud pada koperasi simpan pinjam sudahkah memadai?

Tujuan penelitian adalah untuk mengetahui kompetensi dan pemahaman tentang fraud yg dimiliki pengawas, pengurus dan manajer dalam mendeteksi fraud pada koperasi simpan pinjam sudah memadai atau belum , penelitian diharapkan dapat digunakan sebagai bahan informasi dalam mengembangkan usaha bagi anggota (pemilik), pengurus atau manajer, badan pengawas koperasi mengenai pentingnya kompetensi dan pemahaman fraud dalam mendeteksi terjadinya kecurangan/fraud serta bahan pertimbangan bagi pemerintah dalam penetapan kebijakan untuk mengatasai terjadinya fraud bagi koperasi.

menyesatkan.

Dampak akibat fraud bagi koperasi sungguh luar biasa , bahkan bisa mengakibatkan koperasi mengalami collaps dan ambruk. Kerugian itu bersifat material dan non material antara lain :Menurunnya likuiditas dan kapasitas pelayanan,menurunnya tingkat pendapata, menghambat pelaksanaan program kerja, memperburuk kinerja Lembaga, menurunkan tingkat kepercayaan dan mutu Lembaga, menurunkan semangat kerja, memberburuk citra Lembaga.kan (Ngatidjo,2019) Fraud adalah tindakan yang seolah-olah benar atau bersifat samar-samar, maka perlu kejelian dalam melakukan deteksi.Perlu diketahui pelaku fraud pada dasarnya orang yang cerdik dan cerdas, sehingga tahu dimana celah yang memungkinkan melakukannya . Untuk melakukan pencegahan dan deteksi kemungkinan fraud perlu dilakukan : 1) Pemeriksaan silang (cross check). 2) Pemeriksaan akurasi , kelengkapan , kebenaran keabsyahan terhadap dokumen pengeluaran dan penerimaan. 3) Mewaspai terhadap meningkatnya NPL. 4) Melakukan on the spot untuk memastikan kebenaran psosedur dan akuntansi data pelayanan di lapangan. 5) Melakukan pemeriksaan terhadap seluruh proses pembukuan dan pelaporan keuangan. 6) Analisa keuangan : aktiva, pasiva, cash flow, NPL, BOPO. 7) Pengawasan ketat terhadap pelaksanaan SOM/SOP. 8) Whitleblower (pemberi informasi). 9) Complain Handling (kotak 
pengaduan). 10) Melakukan stok opname terhadap barang inventaris secara berkala.

Pemahaman fraud merupakan suatu kemampuan seseorang untuk mengenal dan mengerti tentang fraud. Tingkat pemahaman fraud ini dapat diukur dari pahamnya seseorang terhadap bentuk modus dari fraud yang dilakukan, pihakpihak yang bisa melakukan fraud dan kegiatan yang dilakukan dalm melakukan fraud. Bentuk modus fraud yang terjadi dalam lingkungan koperasi meliputi : 1) Penggelapan uang atau barang. 2) Kolusi. 3) Manipulasi data dan informasi. 4) Pencurian barang atau data informasi. 5) Gratifikasi. 6) Mark up biaya

Beberapa kegiatan yang dilakukan untuk berpraktek fraud : 1) Kegiatan pelayanan simpanan. 2) Kegiatan pelayanan pinjaman. 3) Penjualan asset. 4) Pengadaan barang dan jasa. 5) Pembukuan dan pelaporan keuangan. 6) Penyalahgunaan asset koperasi Pihak-pihak yang biasanya terlibat adalah : ketua/ manajer, petugas lapangan, kasir. Kompetensi dapat didefinisikan sebagai kemampuan manusia, lembaga dan masyarakat untuk melakukan keberhasilan, untuk mengidentifikasi dan mencapai tujuan mereka untuk mengubah bila diperlukan untuk tujuan keberkelanjutan, pengembangan dan kemajuan. Kompetensi merupakan suatu karakteristik bahwa individu memiliki kemampuan dan digunakan dengan cara yang konsisten bertujuan untuk mencapai suatu kinerja yang diinginkan. Sumber daya manusia merupakan pilar penyangga utama sekaligus penggerak roda organisasi dalam usaha harus dikelola dengan baik untuk mewujudkan visi dan misi serta tujuan organisasi.

Dalam (Undang-Undang Nomor 13 Tahun 2003 Tentang Ketenagakerjaan, n.d.) tentang ketenagakerjaan , bahwa kompetensi kerja adalah kemampuan kerja setiap individu yang mencakup aspek pengetahuan, ketrampilan dan sikap kerja sesuai dengan standar yang ditetapkan . pengetahuan adalah kemampuan yang diperoleh melalui pendidikan, pelatihan dan pengalaman. Pengetahuan akuntansi tidak hanya perlu dimiliki oleh manajer atau pemilik perusahaan, akan tetapi harus dimiliki juga oleh para pemangku kepentingan terhadap pemilik bisnis. Pengetahuan akuntansi yang digunakan dalam penelitian ini yaitu pengetahuan deklaratif dan pengetahuan prosedural (Hendrisna Hana, 2015). Sikap adalah tingkah laku atau gerakan-gerakan yang tampak dan ditampilkan dalam interaksinya dengan lingkungan social, dimana dalam interaksi tersebut ada proses saling merespon, saling mempengaruhi serta saling menyesuaikan diri dengan lingkungan social.

(Permenristekdikti No. 44 Tahun 2015, 2015) tentang Standar Nasional Pendidikan Tinggi ada 10 butir rumusan sikap meliputi : 1) bertakwa kepada Tuhan yang Maha Esa dan mampu menunjukka sikap religious. 2) Menjunjung tinggi nilai kemanusiaan dalam menjalankan tugas berdasarkan agama, moral dan etika. 3) Berkontribusi dalam peningkatan mutu kehidupan bermasyarakat, berbangsa, bernegara dan kemajuan peradaban berdasarkan Pancasila.4) Berperan sebagai warga negara yang bangga dan cinta tanah air, memiliki nasionalisme serta rasa tanggungjawab pada negara dan bangsa.5) Menghargai keanekaragaman budaya, pandangan, agama dan kepercayaan serta pendapat atau temuan orisinal orang lain. 6) Bekerja sama dan memili kepekaan social serta kepeduliaan terhadap masyarakat dan lingkungan.7) Taat hukum dan disiplin dalam kehidupan bermasyarakat dan bernegara. 8) Mengintegrasikan nilai norma dan etika akademik. 9) Menunjukkan sikap bertanggungjawab atas pekerjaan di bidang keahliannya secara mandiri. 10) Menginternalisasi semangat kemandirian, kejuangan dan kewirausahaan.

Ketrampilan umum yang meliputi :1) Mampu menerapkan pemikiran logis, kritis dan sistematis dan inovatif dalam kontek pengembangan ilmu pengetahuan dan teknologi dan memperhatikan dan menerapkan nilai humaniora yang sesuai dengan bidang keahliannya. 2) Mampu menunjujja kinerja mandiri , bermutu dan terukur. 3) Mampu mengkaji implikasi pengembangan atau implementasi ilmu pengetahuan teknologi yang memperhatikan dan menerapkan nilai humaniora sesuai dengan keahliannya berdasarkan kaidah, tata cara, dan etika ilmiah, dalam rangka menghasilkan solusi, gagasan, desain atau kritik sen. 4) Menyusun deskripsi saintifik hasil kajiannya dalam bentuk skripsi, atau laporan tugas akhir dan mengunggahnya dalam laman perguruan tinggi. 5)Mampu mengambil keputusan secara tepat dalam konteks penyelesaian masalah di bidang keahliannya, berdasarkan analisis informasi dan data. 6) Mampu memelihara dan mengembangkan jaringan kerja dengan pembimbing, kolega sejawat 
baik di dalam maupun di luar negeri. 9) mampu bertanggung jawab atas pencapaian hasil kerja kelompok dan melakukan supervise dan evaluasi terhadap penyelesaian pekerjaan yang ditugaskan kepada pekerja yang berada di bawah tanggungjawabnya.

Berdasarkan penjelasan di atas dapat di tarik kesimpulan bahwa kompetensi merupakan suatu kemampuan yang dimiliki oleh individu yang digunakan untuk menyelesaikan tugas yang di berikan.

Model penelitian dapat dilihat pada gambar .berikut.

\begin{tabular}{|l|l|}
\hline $\begin{array}{l}\text { Kompetensi: } \\
\text { - Pengetahuan } \\
\text { - Sikap }\end{array}$ & \multicolumn{1}{|c|}{ Model penelitian } \\
- Ketrampilan & $\begin{array}{l}\text { Mendeteksi Fraud Cross } \\
\text { check Pemeriksaan akurasi } \\
\text { Waspada NPL } \\
\text { Melakukan on the spot } \\
\text { pemeriksaan seluruh proses } \\
\text { Analisis keuangan Cash } \\
\text { opname Pengawasan } \\
\text { SOP Whitleblower } \\
\text { Complain Handling Opname } \\
\text { Pemahaman Fraud } \\
\text {-Bentuk dan modus } \\
\text {-Pihak-pihak yang terlibat } \\
\text { - Jenis -jenis kegiatan }\end{array}$ \\
\cline { 2 - 3 } & \\
\hline
\end{tabular}

Kompetensi merupakan suatu keahlian atau kreatifitas yang dimiliki oleh setiap individu yang tergabung dari berbagai karakteristik antara lain, pengetahuan, keterampilan, sikap yang diadopsi dari Standar nasional Pendidikan Tinggi untuk ketrampilan dan sikap, pengetahuan diadopsi dari penelitian (Hudha, 2017) merupakan pengetahuan deklaratif dan procedural akuntansi, menggunakan pilihan ganda jika betul diberi nilai 1 dan salah diberi nilai 0 , untuk sikap dan ketrampilan diberi nilai sesuai skala linkert $1-5$ poin.

Pemahaman Fraud merupakan suatu

\section{METODE PENELITIAN}

Penelitian dilakukan pada koperasi Simpan Pinjam di wilayah Denpasar Timur Kota Denpasar yang masih aktif berjumlah 28 koperasi, Data kuantitatif antara lain hasil jawaban kuesioner dari responden. Populasi dalam penelitian ini adalah pengurus, pengawas dan manajemen koperasi simpan pinjam yang masih aktif beroperasi di Kecamatan Denpasar Timur yang ijin operasionalnya dikeluatkan oleh Wali Kota Denpasar. Sampel adalah bagian dari jumlah dan karakteristik yang dimliki oleh populasi tersebut (Sugiyono., 2015). Metode penentuan sampel yang digunakan dalam penelitian ini adalah teknik non probability sampling yaitu purposive sampling, yaitu metode penentuan sampel dengan pertimbangan . ertentu. Dengan kriteria sebagai berikut: Responden menduduki jabatan sebagai ketua, ketua pengawas dan manajer dan menduduki kemampuan seseorang untuk mengenal dan mengerti tentang fraud. Jadi orang yang memiliki pemahaman fraud adalah orang yang pandai dan mengerti benar bentuk modus, kegiatan-kegitan dan pihak-pihak yang terlibat dalam fraud.

Mendete fraud merupakan suatu tindakan untuk menemukan kecurangan yang terjadi dengan mempersempit ruang gerak pelaku kecurangan dalam pengelolaan keuangan koperasi. Dengan melakukan tindakan mendeteksi fraud (Ngatidjo, n.d.).

jabatan min 1 tahun.. Dari 51 koperasi yang ada hanya 28 koperasi yang beroperasi saat ini karena sebagian koperasi sudah tidak beroperasi lagi secara permanen dan ada tutup sementara karena pandemi COVID'19, yang memenuhi kriteria sampel sebanyak 61 orang. Instrumen kuesioner harus diukur validitas dan reliabilitasnya, suatu item dikatakan valid jika pernyataan pada kuesioner mampu untuk mengungkapkan sesuatu yang akan diukur oleh kuesioner tersebut (Ghozali, 2013) jika nilai Pearson Correlation $>0,30$ maka butir pertanyaan dikatakan valid. Uji reliabilitas dilakukan dengan menggunakan koefisien crobach alpha $>0,6$.

Analisa kualitatif dan kuantitatif kuantitatif, yaitu teknik analisis data dengan memberikan uraian masingmasing indikator dari variabel yang ada untuk memberi 
suatu simpulan mengenai kompetensi dan pemahaman fraud yang dimiliki badan pengawas dan pengurus dalam mendeteksi fraud di koperasi. Variabel -variabel akan diukur dengan menggunakan skala liket, metode kelas interval dan rata-rata, sesuai tabel berikut

Tabel 1

Kelas Interval Kompetensi, pemahaman fraud dan Deteksi fraud

\begin{tabular}{|c|c|c|c|}
\hline o & Kelas interval & Nilai & Keterangan \\
\hline & $0,8-1,6$ & TM & Tidak Memadai \\
\hline & $1,7-2,5$ & KM & Kurang Memadai \\
\hline & $2,6-3,2$ & CM & Cukup Memadai \\
\hline & $3,3-4,1$ & M & Memadai \\
\hline & $4,2-5,0$ & SM & Sangat Memadai \\
\hline
\end{tabular}

\section{HASIL DAN PEMBAHASAN}

Jumlah semua jenis koperasi di Kecamatan Denpasar Timur Kota Denpasar saat ini berbadan hukum yang dikeluarkan oleh Kota Denpasar sekitar 320 koperasi, yang mana sejumlah 51 koperasi merupakan koperasi simpan pinjam (KSP) banyak KSP yang sudah tidak beroperasi lagi secara permanen ataupun tutup sementara karena pandemi COVID '19 yang membawa dampak sangat besar pada menurunnya tingkat perekonomian masyarakat yang otomatis berdampak juga pada KSP. Merebaknya kasus pandemi COVID 19, Gubernur Bali gelontorkan dana stimulus untuk usaha koperasi yang terdampak (Media Pelangi, 2/6/20), untuk Kota Denpasar 188 koperasi penuhi syarat untuk mendapatkan stimulus tersebut. Di lapangandari $51 \mathrm{KSP}$ hanya ditemui $28 \mathrm{KSP}$ yang masih aktif beroperasi saat pandemic. Sampel yang memenuhi kriteria dari 28 koperasi hanya 61 sampel

Dalam penelitian ini, hasil yang bisa diolah hanya 61 kuisioner yang memenuhi kriteria yaitu dari pengawas sebanyak 27 kuisioner, ketua 23 kuisioner dan manajer 11 kuisioner. Adapun karakteristik yang terkumpul melalui pengumpulan kuisioner adalah sebagai berikut. responden laki-laki lebih banyak daripada responden perempuan yaitu sebanyak 53 orang (87\%), ). responden yang menduduki jabatan $1-5$ tahun terbanyak yaitu sebanyak 38 orang $62.30 \%$ ).

responden yang terbanyak adalah dari KSP yang memiliki total asset >Rp.500.000.000Rp.10.000.000.000 sebanyak 45 orang $(73,8 \%)$, dapat dinyatakan bahwa responden yang terbanyak adalah tingkat pendidikannya sarjana sebanyak 33 orang $(54,1 \%)$. 32 orang(52,45\%) telah mengikuti diklat kompetensi yang diadakan oleh Dinas Koperasi Usaha Kecil \&Menengah

Uji validitas digunakan untuk mengukur sah atau valid tidaknya suatu kuesioner. Suatu kuesioner dikatakan valid jika pernyataan pada kuesioner mampu untuk mengungkapkan sesuatu yang akan diukur oleh kuesioner tersebut. Untuk uji validitas ini menggunakan bantuan program software SPSS. Jika koefesien korelasinya lebih besar dari 0,30 maka indikator dalam variabel dinyatakan valid. Uji validitas pada penelitian ini dilakukan terhadap variabel sikap. Hasil uji disajikan pada Tabel 2

Tabel 2

Hasil Uji Validitas Variabel Sikap

\begin{tabular}{|c|c|c|c|}
\hline $\mathrm{or} \quad \mathrm{N}$ & Indikator & Koefisien Korelasi & Keterangan \\
\hline 1 & SK.1 & 0,600 & Valid \\
\hline 2 & SK.2 & 0,776 & Valid \\
\hline 3 & SK.3 & 0,645 & Valid \\
\hline 4 & SK.4 & 0,724 & Valid \\
\hline 5 & SK.5 & 0,655 & Valid \\
\hline 6 & SK.6 & 0,778 & Valid \\
\hline 7 & SK.7 & 0,821 & Valid \\
\hline 8 & SK.8 & 0,688 & Valid \\
\hline
\end{tabular}




\begin{tabular}{|r|r|c|c|}
9 & SK.9 & 0,611 & Valid \\
\hline 1 & SK.10 & 0,660 & Valid \\
\hline
\end{tabular}

Berdasarkan Tabel 2 diketahui bahwa seluruh Jadi dapat disimpulkan bahwa seluruh indikator telah indikator dalam variabel pengetahuan akuntansi memiliki koefisien korelasi yang lebih besar dari 0,30.

$\begin{array}{lll}\text { Jadi dapat disimpulkan bahwa seluruh indikator telah } \\ \text { memenuhi } & \text { syarat } & \text { validitas }\end{array}$

Tabel 3

Hasil Uji Validitas Variabel Ketrampilan

\begin{tabular}{|c|c|r|c|}
\hline o & Indikator & Koefisien Korelasi & Keterangan \\
\hline & KT.1 & 0,813 & Valid \\
\hline & KT.2 & 0,779 & Valid \\
\hline & KT.3 & 0,824 & Valid \\
\hline & KT.4 & 0,795 & Valid \\
\hline & KT.5 & 0,728 & Valid \\
\hline & KT.6 & 0,870 & Valid \\
\hline & KT.7 & 0,791 & Valid \\
\hline
\end{tabular}

Berdasarkan Tabel 3 diketahui bahwa seluruh indikator dalam variabel ketrampilan memiliki koefisien korelasi yang lebih besar dari 0,30. Jadi dapat

disimpulkan bahwa seluruh indikator telah memenuhi syarat validitas data.

Tabel 4

Hasil Uji Validitas Variabel Pemahaman tentang Fraud

\begin{tabular}{|c|c|r|c|}
\hline o & Indikator & Koefisien korelasi & Keterangan \\
\hline & PF.1 & 0,933 & Valid \\
\hline & PF.2 & 0,922 & Valid \\
\hline & PF.3 & 0,939 & Valid \\
\hline & PF.4 & 0,960 & Valid \\
\hline & PF.5 & 0,959 & Valid \\
\hline & PF.6 & 0,953 & Valid \\
\hline & PF.7 & 0,929 & Valid \\
\hline & PF.8 & 0,937 & Valid \\
\hline 0 & PF.9 & 0,968 & Valid \\
\hline 1 & PF.10 & 0,959 & Valid \\
\hline 2 & PF.11 & 0,959 & Valid \\
\hline 3 & PF.12 & 0,926 & Valid \\
\hline 4 & PF.13 & 0,936 & Valid \\
\hline 5 & PF.14 & 0,927 & Valid \\
\hline
\end{tabular}

Berdasarkan Tabel 4 diketahui bahwa seluruh memiliki koefisien korelasi yang lebih besar dari 0,30. ndicator dalam ndicato pemahaman tentang fraud Jadi dapat disimpulkan bahwa seluruh ndicator telah 
memenuhi syarat validitas data.

Tabel 5

Validitas Variabel Mendeteksi Fraud

\begin{tabular}{|c|c|r|c|}
\hline o & Indikator & Koefisien korelasi & Keterangan \\
\hline & DF.1 & 0,430 & Valid \\
\hline & DF.2 & 0,393 & Valid \\
\hline & DF.3 & 0,462 & Valid \\
\hline & DF.4 & 0,662 & Valid \\
\hline & DF.5 & 0,392 & Valid \\
\hline & DF.6 & 0,421 & Valid \\
\hline & DF.7 & 0,372 & Valid \\
\hline & DF.8 & 0,433 & Valid \\
\hline 0 & DF.9 & 0,441 & Valid \\
\hline
\end{tabular}

Berdasarkan Tabel 5 diketahui bahwa seluruh indikator dalam variabel mendeteksi fraud memiliki koefisien korelasi yang lebih besar dari 0,30. Jadi dapat disimpulkan bahwa seluruh indikator telah memenuhi syarat validitas data
Untuk mengukur reliabilitas dengan uji statistik Cronbach Alpha lebih besar dari 0,60. Hasil uji nilai cronbach alpha menunjukkan semua variabel telah memenuhi syarat reliabilitas data seperti tabel 6 berikut ini.

Tabel 6

\section{Hasil Uji Reliabilitas}

\begin{tabular}{|c|l|c|c|}
\hline o & Variabel & $\begin{array}{c}\text { Nilai Alpha } \\
\text { Cronbach }\end{array}$ & Keterangan \\
\hline & Sikap & 0,891 & Reliabel \\
\hline & Ketrampilan & 0,919 & Reliabel \\
\hline & Pemahaman fraud & 0,995 & Reliabel \\
\hline & Mendeteksi fraud & 0,944 & Reliabel \\
\hline
\end{tabular}

Sumber: Lampiran 2

Dari tabel 6 dapat dilihat semua variabel dengan nilai diatas 0,6 maka semua data reliabel

Berikut tabel 7 mengenai statistic deskriptif

Tabel 7

Descriptive Statistics

\begin{tabular}{|c|r|r|r|r|r|}
\hline & & $\begin{array}{c}\text { Min } \\
\text { imum }\end{array}$ & $\begin{array}{c}\text { Max } \\
\text { imum }\end{array}$ & $\begin{array}{c}\text { Me } \\
\text { an }\end{array}$ & $\begin{array}{c}\text { Std. } \\
\text { Deviation }\end{array}$ \\
\hline $\begin{array}{c}\text { Penget } \\
\text { ahuan }\end{array}$ & 61 & 5.0 & 10.0 & 7.4 & 1.2319 \\
Sikap & 61 & 40.0 & 50.0 & $\begin{array}{c}43 \\
44 .\end{array}$ & 3.5712 \\
$\begin{array}{c}\text { Ketram } \\
\text { pilan }\end{array}$ & 61 & 26.0 & 40.0 & $\begin{array}{c}525 \\
33 .\end{array}$ & 3.1629 \\
\hline
\end{tabular}




\begin{tabular}{|r|r|r|r|r|r|} 
Pemah & 61 & 15.0 & 75.0 & 57. & 18.1460 \\
aman Fraud & & & & 393 & \\
Deteksi & 61 & 38.0 & 50.0 & 44. & 4.0351 \\
Fraud & & & & 426 & \\
Valid & 61 & & & & \\
$\mathrm{~N}$ (listwise) & & & & & \\
\hline
\end{tabular}

Dalam tabel 7 statistik deskriptif dari 61 responden dilihat dari pengetahuan akuntansi dengan nilai minimal 5 dan maksimal 10 dari 10 pertanyaan yang diajukan. Dari sikap nilai minimal 40 dan maksimal 50 dari 10 penyataan tentang sikap. Ketrampilan nilai minimal 26 dan maksimal 40 dari 8 penyataan tentang ketrampilan.
Pemahaman fraud yang dimiliki minimal 15 dan maksimal 75 dari 15 pernyataan tentang pemahaman fraud.

Pengetahuan akuntansi yang dimiliki dapat dilihat pada tabel 8

\section{Tabel 8}

Pengetahuan Akuntansi

\begin{tabular}{|c|c|c|c|c|}
\hline $\begin{array}{c}\text { N } \\
\text { o }\end{array}$ & Betul & $\begin{array}{c}\text { Jumlah } \\
\text { Responden }\end{array}$ & Nilai & Total Nilai \\
\hline 1 & $0-2$ & 0 & 1 & 0 \\
\hline 2 & $3-4$ & 0 & 2 & 0 \\
\hline 3 & $5-6$ & 12 & 3 & 36 \\
\hline 4 & $7-8$ & 38 & 4 & 152 \\
\hline 5 & $9-10$ & 11 & 5 & 55 \\
\hline \multicolumn{2}{|l|}{ Total Skor } & & 243 \\
\hline \multicolumn{2}{|l|}{ Skor rata-rata } \\
\hline
\end{tabular}

Dilihat dari tabel 8 pengetahuan akuntansi yang dimiliki dengan hasil perhitungan skor rata-rata sebesar 3,98 pada katagori memadai menunjukkan penengetahuan akuntansi yang dimiliki oleh ketua, pengurus dan manajer KSP di wilayah Kecamatan Denpasar Timur Kota Denpasar secara deklaratif dan procedural dalam melakukan aktivitasnya. Ketua, pengawas dan para manajer sebagian besar sudah melakukan diklat dalam pengelolaan KSP seperti diklat akuntansi, manajemen, kompetensi, pengawasan tentang koperasi. Pengetahuan akuntansi dalam penelitian ini yaitu pengetahuan dari ketua, pengawas dan pengurus tentang akuntansi. Hal ini dapat tercemin melalui perlakuan dalam mengelola keuangan KSP. Yang mana praktik akuntansi dalam perusahaan mencerminkan

$$
\text { Tabel } 9
$$

Hasil perhitungan Sikap, Ketrampilan, Pemahaman Fraud dan Deteksi Frauf

\begin{tabular}{|c|c|c|c|c|c|}
\hline o & Betul & $\begin{array}{c}\text { Total } \\
\text { Jawaban } \\
\text { Kuisioner }\end{array}$ & $\begin{array}{c}\text { Jumlah } \\
\text { Pernyataan x } \\
\text { Jumlah responden }\end{array}$ & $\begin{array}{c}\text { Rat } \\
\text { a-Rata } \\
\text { Skor }\end{array}$ & Katagori \\
\hline & 2 & 3 & 4 & $5=$ & 6 \\
\hline & Sikap & 2716 & 610 & 4,4 & $\begin{array}{c}\text { Sangat } \\
\text { Memadai }\end{array}$ \\
\hline
\end{tabular}




\begin{tabular}{|r|r|c|c|c|c|}
\hline & $\begin{array}{c}\text { Ketra } \\
\text { mpilan }\end{array}$ & 2061 & 488 & $2^{4,2}$ & $\begin{array}{c}\text { Sangat } \\
\text { Memadai }\end{array}$ \\
\hline $\begin{array}{r}\text { Pemah } \\
\text { aman Fraud }\end{array}$ & 3501 & 915 & $3^{3,8}$ & Memadai \\
\hline $\begin{array}{r}\text { Deteks } \\
\text { i Fraud }\end{array}$ & 2710 & 610 & $4^{4,4}$ & $\begin{array}{c}\text { Sangat } \\
\text { Memadai }\end{array}$ \\
\hline
\end{tabular}

Sikap yang mencerminkan tingkah laku atau gerakan-gerakan yang tampak dalam interaksi sosial yang beretika berdasarka Pancasila yang dimiliki oleh ketua, pengawas dan manajer sangat memadai dengan skor rata-rata 4,45. Dengan tingkat ketakwaan kepada Tuhan Yang maha Esa, memjunjung tinggi niklai kemanusiaan dalam meningkatkan taraf hidup berdasarkan Pancasila, memiliki sikap nasionalisme, bertanggungjawab dan taat hukum maka ketua, pengawas dan manajer akan melaksanakan tugasnya sesuai dengan aturan yang berlaku yang menjiwai nilainilai pancasila sehingga mendeteksi fraud yang ada pada KSP itu adalah merupakan tanggungjawabnya

Ketrampilan merupakan keahlian yang dimuliki oleh seseorang dalam bidangnya, Ketrampilan yang dimiliki dalam penelitian ini dengan skor rata-rata 4,22 dalam katagori sangat memadai. Ketrampilan yang dimiliki oleh ketua, pengurus dan manajer dalam menjalankan tugas sudah sangat baik, yang mampu menunjukkan kinerja mandiri, bermutu, berpikiran logis, mampu melakukan proses evaluasi dalam KSP sesuai dengan tugasnya masing-masing.

Pemahaman fraud merupakan proses, cara dan tindakan dalam memahami kecurangan. Berdaasrkan

\section{KESIMPULAN DAN SARAN}

Berdasarkan rumusan masalah, perhitungan skor dapat disimpulkan Kompetensi yang dimiliki oleh manajer, pengurus dan pengawas pada KSP di Denpasar Timur dilihat dari pengetahuan akuntansinya memadai dengan skor rata-rata 3,98, sikap yang dimiliki sangat memadsai dengan skor 4,45 dan ketrampilan yang dimiliki sangat memadai dengan skor rata-rata 4,22. Pemahama fraud yang dimiliki memadai dengan skor rata-rata 3,83 dan kemampuan memdeteksi fraud yang dimiliki oleh manajer,pengurus dan pengawas KSP di

\section{DAFTAR PUSTAKA}

Ghozali, I. (2013). Aplikasi Aanalisis Multivariate dengan Program IBM SPSS 21 Update PLS Regresi. Badan Penerbit Universitas Diponegoro.

Hendrisna Hana. (2015). Pengaruh Pengetahuan Akuntansi dan Kepribadian Wirausaha Terhadap Penggunaan Infromasi Akuntansi.

Hudha, C. (2017). Pengaruh Tingkat Pendidikan, Pengetahuan Akuntansi dan Pelatihan Akuntansi Terhadap Penggunaan Informasi Akuntansi Dimoderasi Ketidakpastian Lingkungan Usaha Kecil Menengah. skor rata-rata sebesar 3,83 pemahaman yang dimiliki berada pada katagori memadai . KSP di kecamatan Denpasar Timur ketua, pengawas dan manajernya memiliki pemahaman berbagai bentuk modus fraud, jenis-jenis kegiatan sebagai berprakteknya fraud dan pihak-pihak yang biasanya terlibat dalam terjadinya fraud pada KSP

Mendeteksi fraud merupakan upaya untuk mendapatkan indikasi awal yang cukup mengenai tindakan penemuan kecurangan, sekaligus mempersempit ruang gerak para pelaku kecurangan (Kumaat, 2011). Berdasarkan skor nilai rata-rata deteksi fraud sebesar 4,44 yang berada pada katagori sangat memadai. Tindakan yang dilakukan dalam mendeteksi fraud yang mungkin terjadi. Ketua, pengawas dan manajer dalam KSP di Denpasar Timur sudah sangat mampudalam mendeteksi fraud yaitu dengan melakukan berbagai tindakan cross check, mewaspadai adanya NPL, melakukan pemeriksaan proses pembukuan, pengawasan SOP, cash opname, on the spot, membuat kotak pengaduan, dengan demikian mereka yang berniat melakukan fraud akan berpikir berkali-kali sebelum melakukan aksinya

Denpasar timur dengan skor rata-rata 4, 45 sangat memadai

Diharapk tidak saja ketua, pengawas dan manajer yang memiliki kompetensi, tetapi semua komponen yang ada pada KSP memiliki kompetensi sesuai dengan bidangnya dalam melakukan pekerjaan. sehingga KSP dapat berkembang dengan baik. Untuk penelitiann selanjutnya dapat menggunakan sampel penelitian yang lebih banyak dengan wilayah lebih luasagar dapat menarik kesimpulan yang lebih kuat dan juga menambah variabel lain yang berkaitan dengan fraud
Jurnal Ekonomi Pendidikan Dan Kewirausahaan, 5(1), 68-90.

Kumaat. (2011). Internal Audit.

Ngatidjo. (n.d.). Praktek Fraud Di Lingkungan Koperasi. Manajemen Bisnis. UMKM Jogja.

Paula Chrestina Hendrawati. (2017). Pengawasan Koperasi Kredit. Media Nusa Creative. Tentang Penyelenggaraan Dan Pembinaan Koperasi, (2018).

Sugiyono. (2015). Metode Penelitian Kombinasi (Mixed Methods). Alfabeta. 
Permen KUMK No, 15/Per/M.KUMK/IX/2015.

Undang-Undang Nomor 13 tahun 2003 tentang Ketenagakerjaan.

Undang-Undang Nomor 25 tahun 1992 Tentang Perkoperasian, (1992).

Undang-Undang Nomor 17 Tahun 2012 Tentang Perkoperasian, (2012).

Permenristekdikti No. 44 tahun 2015, (2015). 